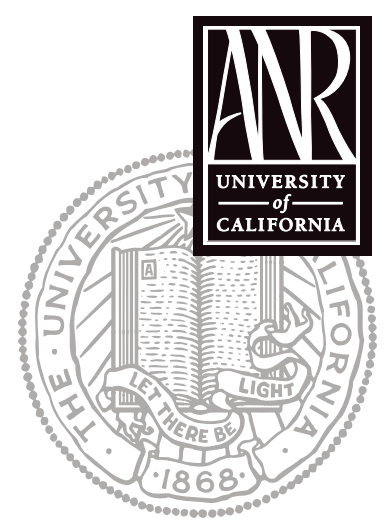

UNIVERSITY OF CALIFORNIA

Division of Agriculture and Natural Resources http://anrcatalog.ucdavis.edu

\title{
Growing Tomatoes in the Home Garden
}

DENNIS R. PITTENGER, University of California Cooperative Extension Area Horticulture Advisor; NANCY F. GARRISON, University of California Cooperative Extension Horticultural Advisor, Santa Clara County; PAMELA M. GEISEL, University of California Cooperative Extension Landscape and Turf Management Farm Advisor, Fresno County; CAROLYN L. UNRUH, staff writer, University of California Cooperative Extension, Fresno County

Tomatoes are among the most popular vegetables grown in home gardens. They also prompt frequent cultural and pest management questions, though many problems can be avoided by planting disease-resistant varieties that are well adapted for your growing area. Most tomato varieties available to the home gardener produce flavorful and juicy fruit and require relatively little space for a large yield. When properly cared for, each tomato plant can bear 10 to 15 pounds ( 4.5 to $6.8 \mathrm{~kg}$ ) or more of fruit.

Deciding which tomato variety to plant may seem a difficult task, given the large number that are available and the differences in size, habit, and climatic requirements. In addition to the usual round red tomato, home gardeners can choose to grow orange, yellow, pink, or striped tomato varieties, or those shaped like pears, grapes, or plums. Often these unusual varieties are available only to the home market and may be grown on limited acreage as they may have little commercial appeal. Some yellow tomatoes have a mild, sweet flavor with low acid content. Ask gardening friends and neighbors for the names of their favorites, and don't overlook the heirloom varieties that are also available.

Tomatoes are described as determinate or indeterminate based on the plant's growth habit. Determinate, or "bush," tomato plants have a somewhat bushy appearance, grow to a given size, about 3 to 5 feet $(0.9$ to $1.5 \mathrm{~m})$, bear most of their fruit within about 4 to 6 weeks, and then decline in vigor. Most early-ripening and canning tomato varieties are of the determinate type.

Indeterminate varieties produce vines that continue to grow and set fruit all summer until they are killed by frost or disease. Many typical standard-sized tomatoes for the home garden are indeterminate varieties. Unless supported by sturdy trellises, cages, or stakes, indeterminate plants tend to sprawl on the ground, leaving the fruit susceptible to rot where it comes in contact with the soil.

Some tomato varieties can be grown successfully in many parts of California, while others have more specific climatic requirements and do well only in certain locales. Although tomatoes are a warm-season crop, they can be grown in the cooler areas of the state if you choose varieties adapted to cooler temperatures or a shorter growing season.

Three climatic zones (A, B, and C) are described below. University of California researchers in each of the three zones evaluated several tomato varieties for growth and production and recommended those varieties for use in the zones in which they proved successful (see table 1). Many other popular tomato varieties have yet to be evaluated in this way.

\section{CLIMATE ZONES FOR TOMATO VARIETIES}

\section{Zone A}

Coastal areas from Santa Barbara south; coastal foothills and mountain ranges from San Diego through Marin Counties; foothills surrounding the Central Valley, Napa, 
and Sonoma Valleys; the cities of San Jose, Los Angeles, Santa Ana, and San Diego; and other areas where summer daytime temperatures are warm but usually below $95^{\circ} \mathrm{F}\left(35^{\circ} \mathrm{C}\right)$.

\section{Zone B}

Inland valleys and high and low deserts; the Central, Sacramento, San Fernando, and San Gabriel Valleys; interior valleys of San Diego County; the cities of Redding, Sacramento, Fresno, Bakersfield, Pomona, Riverside, El Cajon; and other inland areas where daytime temperatures regularly exceed $95^{\circ} \mathrm{F}\left(35^{\circ} \mathrm{C}\right)$ during the summer growing season.

\section{Zone C}

Intermediate central and northern coastal areas; cool coastal valleys from Santa Maria north to the Oregon border; the San Francisco Peninsula and areas with direct exposure to San Francisco Bay; northern coastal foothills; most mountains and mountain valley regions; the cities of Santa Maria, Monterey, Santa Cruz, San Francisco, Oakland, and Eureka; and other areas with cool to moderate summers with evening temperatures frequently in the $45^{\circ}$ to $55^{\circ} \mathrm{F}\left(7.2^{\circ}\right.$ to $\left.12.8^{\circ} \mathrm{C}\right)$ range.

\section{DISEASE RESISTANCE}

For best results, choose tomato varieties that have been developed for disease resistance (see table 1). Tomatoes are susceptible to several disorders that can significantly diminish yield or even destroy an entire tomato crop, but many hybrid tomato varieties are resistant to them. The disease identification codes shown below should be marked on the plant label or seed packet following the tomato's cultivar name.
A Alternaria stem canker
F Fusarium wilt
FF Fusarium, races 1 and 2
FFF Fusarium, races 1,2 , and 3
N Nematodes
T Tobacco mosaic virus (TMV)
St Stemphylium gray leaf spot
V Verticillium wilt

Using this code system, it can easily be determined that the variety Super Marzano Hybrid VFNT is resistant to Verticillium, Fusarium, nematodes, and TMV, while Golden Boy Hybrid A demonstrates resistance only to Alternaria. Note that "resistance" is not equivalent to "immunity." In areas where these problems have occurred in the past, even disease-resistant varieties may encounter some difficulty attaining full growth and production. For that reason, it is recommended that home gardeners follow a crop rotation schedule and avoid planting tomatoes or other members of the nightshade (Solanaceae) family in the same location more than 2 years consecutively.

For more information about these diseases of tomatoes, see UC IPM Pest Management Guideline: Tomato at the UC IPM Web site, http://WwW.ipm.ucdavis.edu/ PMG/selectnewpest.tomatoes.html. This site is intended primarily for commercial growers, but it contains photographs and information of interest to home gardeners.

\section{SELECTED TOMATO VARIETIES}

Table 1 indicates resistance to diseases, adaptation to climatic zones in the state, and days to maturity for selected cherry tomato varieties, container varieties, and stan- 
Table 1. Selected tomato varieties

\begin{tabular}{|c|c|c|c|c|c|c|}
\hline Variety* & Zone $^{\dagger}$ & Vine habit and size & Color & Fruit size & Maturity (days) & Comments \\
\hline \multicolumn{7}{|l|}{ CHERRY TYPES } \\
\hline Cherry Grande Hybrid VF & $A, B, C$ & determinate, medium & red & large cherry & 65 & globe-shaped fruit \\
\hline Green Grape & - & indeterminate, vigorous & green & medium cherry & 70 & unusual heirloom variety \\
\hline Juliet Hybrid & - & indeterminate & red & large cherry & 60 & elongated fruit, AAS winner \\
\hline Large Red Cherry & $A, B, C$ & indeterminate, large & red & large cherry & 72 & prolific \\
\hline Sungold & $A, B, C$ & indeterminate, large & orange & medium cherry & 57 & very early, heavy crop \\
\hline Super Sweet 100 Hybrid VF & $A, B, C$ & indeterminate, large & red & small cherry & 65 & clusters of fruit \\
\hline Sweet Chelsea Hybrid VFFNT & $A, B, C$ & indeterminate, large & red & large cherry & 64 & crack resistant \\
\hline Yellow Pear & $A, B, C$ & indeterminate, large & yellow & medium cherry & 78 & pear-shaped fruit \\
\hline \multicolumn{7}{|l|}{ CONTAINER TYPES } \\
\hline Better Bush Hybrid VFN & $A, B, C$ & determinate, compact & red & small to medium & 68 & early, good in containers \\
\hline Patio Hybrid VASt & $A, B, C$ & determinate, compact & red & small to medium & 70 & extrememly compact growth \\
\hline Small Fry VFNASt & $A, B, C$ & determinate, compact & red & small cherry & 65 & AAS winner \\
\hline Toy Boy VF & $A, B, C$ & determinate, compact & red & small cherry & 55 & very early \\
\hline \multicolumn{7}{|l|}{ STANDARD TYPES } \\
\hline Ace Hybrid & $A, B$ & determinate & red & large & 80 & thick-skinned fruit \\
\hline Beefmaster Hybrid VFNASt & - & indeterminate & red & very large & 80 & fruit up to $2 \mathrm{lb}(0.9 \mathrm{~kg})$ each \\
\hline Better Boy Hybrid VFNASt & $A$ & indeterminate & red & large & 75 & midseason \\
\hline Big Pick VFNT & $A, B$ & indeterminate & red & medium & $70-80$ & midseason \\
\hline Big Set VFN & $A, B$ & semi-determinate, medium & red & medium & 75 & late-season, very heavy crop \\
\hline Bingo VFT & $A, C$ & determinate, medium & red & large & 75 & exceptional flavor, crack resistant \\
\hline Brandywine OTV & - & indeterminate & rosy & large & $90-100$ & Amish heirloom variety \\
\hline Carmelo VFNT & $\mathrm{C}$ & semi-determinate, medium & red & large & 70 & crack resistant, heirloom variety \\
\hline Celebrity Hybrid VFFNTASt & $A, B$ & semi-determinate, medium & red & large & 70 & consistently large fruit, AAS winner \\
\hline Champion Hybrid VFNT & $A, B, C$ & indeterminate, large & red & large & 62 & winter crop in inland valleys \\
\hline Early Bush 76 VF & $A, B$ & determinate, medium & red & large & 65 & best determinate plant for Zone $\mathrm{A}$ \\
\hline Early Girl Hybrid VFF & $A$ & indeterminate, large & red & small to medium & 57 & continuous bearing of fruit \\
\hline Early Pick Hybrid VF & $A, B, C$ & indeterminate, large & red & medium to large & 65 & abundant fruit \\
\hline First Lady II Hybrid VFNTASt & - & indeterminate & red & medium & 66 & very early \\
\hline Floramerica Hybrid VFFASt & $A, B$ & determinate, medium & red & large & 70 & AAS winner \\
\hline Giant Belgium & - & indeterminate & red & large & $82-90$ & heirloom variety \\
\hline Goliath Hybrid VF & - & indeterminate, vigorous & red & large & 78 & heirloom variety \\
\hline Green Zebra & - & determinate, vigorous & green & small to medium & 78 & pale green stripes on fruit \\
\hline Jackpot Hybrid VFFNASt & $A, B$ & determinate, compact & red & medium to large & 70 & concentrated production of fruit \\
\hline Jet Star Hybrid VF & $A, B$ & indeterminate, compact & red & medium to large & 70 & good quality fruit \\
\hline Jeweled Enchantment Hybrid & - & indeterminate, vigorous & red & medium & 68 & paste type, widely adapted \\
\hline Legend & - & determinate & red & large & 68 & fruit up to $1 \mathrm{lb}(454 \mathrm{~g})$ each \\
\hline Lemon Boy Hybrid VFNASt & - & indeterminate & yellow & large & 72 & tangy flavor, productive plant \\
\hline Merced & - & determinate & red & large & 74 & good heat-setting ability \\
\hline Pineapple & - & indeterminate & yellow & large & $85-90$ & red streaks in fruit, heirloom variety \\
\hline Quick Pick VFNT & $A$ & indeterminate, large & red & small to medium & 60 & good-quality fruit \\
\hline Roma VFA & - & determinate & red & small to medium & 75 & paste type \\
\hline Royal Flush VFN & $A, B$ & determinate, compact & red & large & 70 & concentrated production of fruit \\
\hline Shady Lady & B & determinate & red & medium to large & 75 & excellent flavor \\
\hline Supersteak VFN & $A$ & indeterminate, very large & red & very large & 80 & high-quality fruit \\
\hline Valerie VFN & $A, C$ & determinate, medium & red & medium & 60 & early \\
\hline Whopper CR Improved VFFNT & $A$ & indeterminate, large & red & large & 65 & early, crack resistant \\
\hline $\begin{array}{ll}\text { Notes: } & { }^{*} \text { Disease resistance key: } \\
& \text { N Nematodes T Toba }\end{array}$ & $\begin{array}{l}\text { A Alternar } \\
\text { mosaic viru }\end{array}$ & $\begin{array}{l}\text { Inker F Fusarium wilt FF Fusa } \\
\text { St Stemphylium gray leaf spot }\end{array}$ & $\begin{array}{l}\mathrm{m} \text {, races } 1 \\
\text { Verticilliun }\end{array}$ & FFF Fusarium, races & , and 3 & \\
\hline $\begin{array}{r}\text { †one key: A: Coastal areas from Sa } \\
\text { of San Jose, Los Ange } \\
\text { B: Inland valleys and hig } \\
\text { Pomona, Riverside, El } \\
\text { C: Intermediate central a } \\
\text { northern coastal footl } \\
\text { summers with evenin } \\
\text { - Variety not yet evalua }\end{array}$ & $\begin{array}{l}\text { ta Barbara } \\
\mathrm{s} \text {, Santa An } \\
\text { and low de } \\
\text { ajon; and o } \\
\text { id northern } \\
\text { lls; most mo } \\
\text { temperatur } \\
\text { ed by UC re }\end{array}$ & $\begin{array}{l}\text { astal foothills and mountain range } \\
\text { n Diego; and other areas where sur } \\
\text { Central, Sacramento, San Fernand } \\
\text { nd areas where daytime temperatu } \\
\text { reas; cool coastal valleys from Sant } \\
\text { and mountain valley regions; the ci } \\
\text { ntly in the } 45^{\circ} \text { to } 55^{\circ} \mathrm{F}\left(7.2^{\circ} \text { to } 12.8\right. \\
\text { s for climatic adaptation. }\end{array}$ & $\begin{array}{l}\text { rom San Di } \\
\text { eer daytim } \\
\text { and San G } \\
\text { regularly } \\
\text { Maria nortt } \\
\text { s of Santa } \\
\text { ) range. }\end{array}$ & $\begin{array}{l}\text { ough Marin Counties; } f \\
\text { ratures are warm but } \\
\text { alleys; interior valleys o } \\
95^{\circ} \mathrm{F}\left(35^{\circ} \mathrm{C}\right) \text { during the } \\
\text { Oregon border; the Sa } \\
\text { Monterey, Santa Cruz, }\end{array}$ & $\begin{array}{l}\text { hills surrounding the Cen } \\
\text { ally below } 95^{\circ} \mathrm{F}\left(35^{\circ} \mathrm{C}\right) \text {. } \\
\text { an Diego County; the citie } \\
\text { nmer growing season. } \\
\text { rancisco Peninsula and ar } \\
\text { Francisco, Oakland, and }\end{array}$ & $\begin{array}{l}\text { ral Valley, Napa, and Sonoma Valleys; the cities } \\
\text { of Redding, Sacramento, Fresno, Bakersfield, } \\
\text { ureka; and other areas with cool to moderate }\end{array}$ \\
\hline
\end{tabular}


dard-sized varieties. "Days to maturity" is the number of days from transplant to first picking of ripe fruit. It is a relative figure and varies with weather conditions, cultural practices, and the date of transplanting.

\section{Cherry Tomatoes}

Cherry tomatoes have small, cherry-sized (or a little larger) fruit often used in salads or relish trays. Cherry tomatoes grow in all three zones of the state, with plants ranging in size from dwarf to well over 6 feet $(1.8 \mathrm{~m})$ tall. One standard cherry tomato plant is usually sufficient for a family, since they produce abundantly.

\section{Container Varieties}

Container varieties are adapted to all three zones of the state. Midget, patio, or dwarf tomato varieties are ideal for small-space gardening, as they have very compact vines and do best when grown in 5-gallon (20-1) or larger containers, or in large hanging baskets. Some produce fairly large fruit, but the fruit are often of poorer quality than fruit from standard-sized plants. Container varieties are usually short-lived, producing their crop quickly over a short period.

\section{Standard-sized Varieties}

Standard-sized varieties may be adapted to specific climatic conditions of temperature and length of growing season. They produce fruit ranging from a few ounces each to Beefsteak types that may weigh as much as 2 pounds $(1 \mathrm{~kg}$ ) or more and easily cover a sandwich with a single slice. Beefsteak tomatoes are usually late to ripen, so plant some standard-sized, early tomatoes along with them for a longer harvest.

\section{TOMATO CULTURE}

Although many home gardeners prefer to purchase transplants for their vegetable gardens, tomato plants may also be started indoors from seed. Seeds should be sown 6 to 8 weeks before the last spring frost date in your area. Planting seeds too early will require keeping them indoors until the danger of frost has passed and may result in leggy, brittle plants. Planting too late delays your summer's harvest. Tall, spindly transplants are usually the result of low light levels in the home. Tomatoes require plenty of light to grow into sturdy plants, so unless you have a sunny, south-facing window, a supplemental light source like fluorescent "grow lights" will be necessary.

Sow seed about $1 / 4$ inch $(6.5 \mathrm{~mm})$ deep in a clean, light soil mix and keep them warm, about $70^{\circ}$ to $80^{\circ} \mathrm{F}\left(21.1^{\circ}\right.$ to $\left.26.7^{\circ} \mathrm{C}\right)$, and evenly moist until the seedlings appear. If the soil mix already contains fertilizer, it may be unnecessary to add additional fertilizers until after transplanting. If not, fertilize with a diluted (one-half strength) mixture of water-soluble all-purpose fertilizer every 10 to 15 days. Once the seeds have sprouted, they will need 6 to 8 hours of bright light per day and regular irrigation, but they will grow well at temperatures from $65^{\circ}$ to $75^{\circ} \mathrm{F}\left(18.3^{\circ}\right.$ to $\left.23.9^{\circ} \mathrm{C}\right)$.

A week to 10 days before transplanting into the garden, indoor-grown plants need to become acclimated to outdoor conditions of direct sunlight, wind, and cooler nighttime temperatures. This process is called "hardening off" and yields sturdier and more rapidly growing plants after transplanting. Expose the young plants to an increasing number of hours of outdoor light and temperatures each day until they tolerate at least 6 hours of outdoor conditions. Start by placing the plants in a sheltered location such as a cold frame or covered patio, and gradually expose them to garden conditions as weather permits. Bring plants inside if there is danger of frost.

After the danger of frost has passed, tomatoes can be transplanted into the prepared garden site. Tomatoes thrive in most average garden soils in locations that receive full sun and adequate irrigation. Refer to Vegetable Garden Basics 


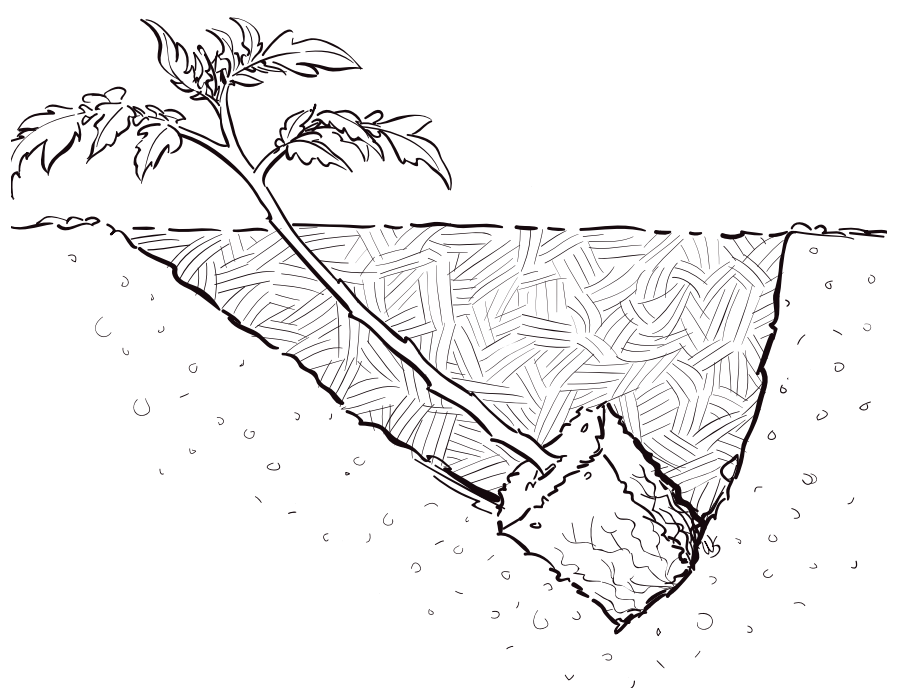

Figure 1. Set tall, lanky tomato plants horizontally into the soil with just a few leaves above the ground. Illustration by Will Suckow.
(UC Agriculture and Natural Resources Publication 8059, http://anrcatalog.ucdavis.edu/pdf/8059.pdf) for information regarding site selection and preparation.

Whether home-grown or purchased, tomato transplants should be about 6 to 8 inches ( 15 to $20.5 \mathrm{~cm}$ ) tall, sufficiently hardened-off, stocky, and well covered with healthy green leaves. Water them thoroughly a couple hours before setting them out and, if possible, plant them in late afternoon so water loss from the plants will be minimized during the cooler overnight hours. Roots will form on buried portions of the stems of tomato plants, so vigorous, compact transplants can be planted about 2 inches $(5 \mathrm{~cm})$ deeper than they are in the pot. For taller, lanky plants with few leaves, pinch off the lower leaves and set the plants into the soil horizontally with just a few sets of top leaves showing above the ground (fig. 1).

During planting, avoid damaging the roots. If the seeds were planted in biodegradable containers such as peat or paper pots, do not remove the containers, but break them up slightly so the roots can easily grow out into the surrounding soil. Be sure to bury peat or paper pots completely to avoid "wicking" of water away from the root zone. If plastic or other nonbiodegradable containers were used, ease the plants out of the pots before transplanting and gently loosen the roots somewhat. Avoid bruising the main stems of transplants - try to handle them by the leaves or root ball (fig. 2). Press soil firmly around each transplant so that a slight depression is formed for hold-

ing water, then water in thoroughly to settle the soil

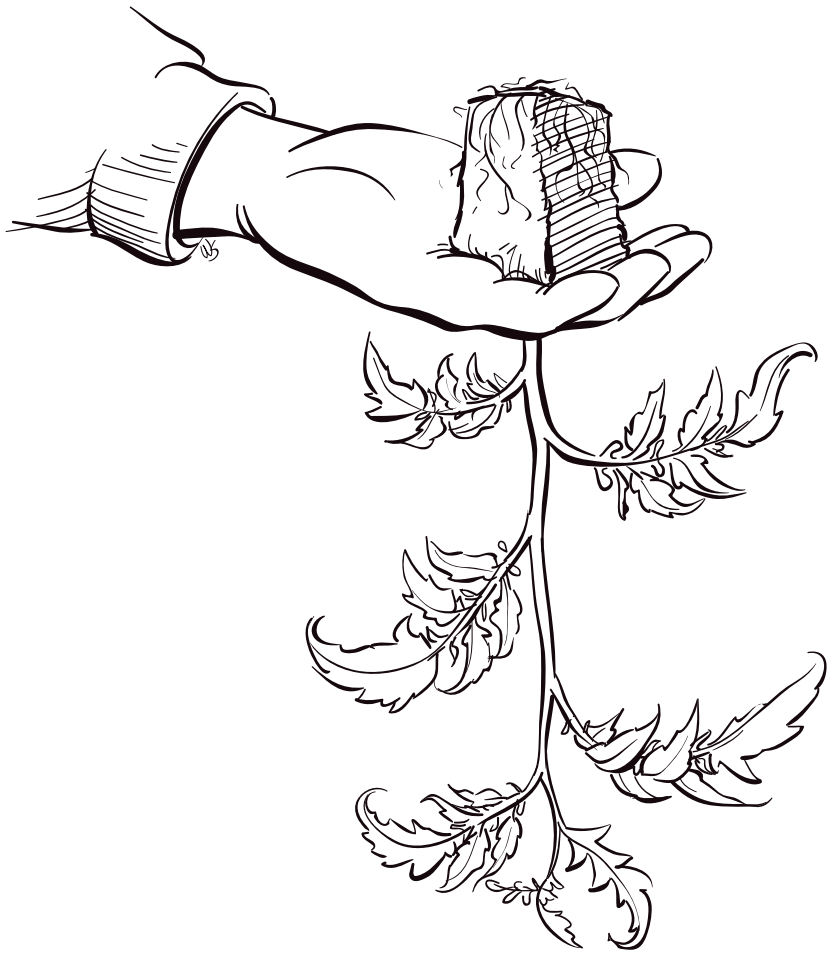

Figure 2. Avoid handling the stems or root ball of tomato transplants. Illustration by Will Suckow. and eliminate any air pockets around the roots.

\section{PLANT SUPPORT}

Tomatoes require plenty of room to grow well. Space rows of staked or caged tomatoes approximately 30 to 42 inches ( 0.8 to $1.1 \mathrm{~m}$ ) apart, and allow 24 to 30 inches ( 61 to $76 \mathrm{~cm}$ ) between plants in each row. If plants cannot be staked, rows should be spaced 6 feet $(1.8 \mathrm{~m})$ apart, with 4 feet $(1.2 \mathrm{~m})$ between plants in the rows for adequate air circulation and plant development.

Virtually all indeterminate plants require some type of support, and many determinate types benefit from staking or caging as well. Though providing support requires more initial work, it makes caring for tomatoes easier than letting them sprawl on the ground. Since the fruit is off the ground, damage from rot and insects is reduced. Spraying is easier and may be required less often, harvesting is much less work, and the plants take up far less space in the garden. The three most often used techniques for support are caging, staking, and trellising. 


\section{Cages}

Growing tomatoes in wire cages is a popular method among gardeners because of its simplicity. Shortly after plants are established, place cylindrical cages around them. Two strong stakes on either side of the cage prevent the fruit-laden plants from blowing over from wind or weight. Metal fencing or concrete reinforcing wire ("remesh") can be used for this purpose, and ready-made cages can be found at garden centers. Usually a cage about 3 to 6 feet $(0.9$ to $1.8 \mathrm{~m})$ tall and 18 to 30 inches ( 46 to $76 \mathrm{~cm}$ ) in diameter works well; a 6-foot (1.8-m) length of fencing makes a cage 19 inches (48 $\mathrm{cm})$ in diameter. Use shorter cages for determinate varieties and taller ones for indeterminate types. Be sure that openings in the cage material are at least 6 inches (15 $\mathrm{cm}$ ) square to permit you to reach through and harvest the fruit. Tomato plants in wire cages do not require pruning, but some gardeners prefer to prune plants to 3 or 4 main stems to keep them more manageable.

Cage growing allows the tomato plant to grow in its natural manner, but keeps the fruit and leaves off the ground, offering the advantages of staking as well. Wirecage tomatoes develop a heavy foliage cover, reducing sunscald on fruit. Caged plants are less prone to the spread of disease from plant handling, since they have fewer open wounds and must be handled less frequently than staked plants. However, it helps to space the plants somewhat farther apart, at least 3 feet $(0.9 \mathrm{~m})$ to allow good air circulation between plants. Humidity is higher because of the foliage density, and diseases such as late blight spread rapidly in humid situations. If well nourished and cared for, caged tomatoes can make up for the extra space required with exceptional harvests.

\section{Stakes}

Some gardeners prefer to stake tomatoes for support. Use sturdy wooden stakes 6 feet $(1.8 \mathrm{~m})$ long and $1 \frac{1}{2}$ to 2 inches $(3.8$ to $5 \mathrm{~cm}$ ) wide. Drive them 1 foot $(30 \mathrm{~cm})$ into the soil about 4 to 6 inches $(10$ to $15 \mathrm{~cm}$ ) from the plant soon after transplanting. Attach heavy twine or strips of cloth to the stakes every 10 inches $(25.5 \mathrm{~cm})$. As the plants grow, pull the stems toward the stakes and tie loosely.

Staked tomato plants usually require pruning to a few main stems. At the junction of each leaf and the first main stem, a new shoot will develop. Choose one to three of these shoots, normally at the first and second leaf-stem junction, for the additional main stems. Once a week, pinch off most of the other shoots, called "suckers," with your fingers to keep the plants from becoming too large for their support.

\section{Trellises}

Trellising is similar to staking in that plants are tied at regular intervals and pruned in a manner similar to that used with stakes. Plants may be set along a fence or planted near a large, strong trellis, then trained upward as they grow.

\section{WATER AND FERTILIZER}

Tomatoes are medium in rooting depth and need regular irrigation during the growing season. Avoid extreme fluctuations in soil moisture, as these conditions increase the incidence of fruit cracking and blossom end rot. Weeds should be kept to a minimum, since they compete with the tomatoes for water and nutrients and may harbor insect and disease pests. A layer of coarse mulch 3 to 4 inches $(7.5$ to $10 \mathrm{~cm})$ deep of a material such as compost will help reduce soil moisture fluctuations, moderate soil temperatures, and discourage emergence of weeds. 
Healthy, vigorous transplants should not require additional fertilizer until flowering and fruit set are well under way. Excessive nitrogen fertilizer during the initial growth period results in lush, green vegetative growth, but will delay flowering and fruit set and make the plants more attractive to insect pests such as aphids and hornworms. At fruit set, plants can be sidedressed with nitrogen fertilizer every 4 to 6 weeks, following instructions on the product label. To sidedress, place fertilizer at the sides of the growing plants in shallow grooves or on the soil surface, then thoroughly water the fertilizer into the root zone to assure effective use by the plants. If manure or preplant fertilizer was used in preparing the planting site, reduce the rate of fertilizer application by one-half. Avoid applying more fertilizer than necessary, as excess nitrogen may be leached past the root zone and cause contamination of the groundwater supply.

For best flavor, harvest when fruit are at full color for the variety-rich red, orange, or yellow. Ripe tomatoes should be stored at $55^{\circ}$ to $70^{\circ} \mathrm{F}\left(12.8^{\circ}\right.$ to $\left.21.1^{\circ} \mathrm{C}\right)$ to maintain their fresh, ripe flavor. Lengthy refrigeration causes flavor loss and browning discoloration of fruit. Toward the end of the season, there are usually some whitishgreen, full-size tomatoes still on the vines. You can pick these tomatoes and store them at $70^{\circ} \mathrm{F}\left(21.1^{\circ} \mathrm{C}\right)$ to ripen. Place harvested immature tomatoes in a shaded location to further ripen the fruit. Light is not necessary for ripening immature tomatoes.

\section{ABIOTIC DISORDERS OF TOMATOES}

Home gardeners may experience disappointing results when growing tomatoes because the plants and fruit are susceptible to several common abiotic disorders, as well as attack by diseases and other pests. Abiotic disorders result from nonliving causes and are often attributable to environmental or cultural factors, or simply to the plant's genetic makeup.

\section{Flower Drop and Failure to Set Fruit}

\section{Problem}

- Blossoms fall off.

- Plant fails to set fruit.

\section{Probable Cause}

- Night temperatures too low, below $55^{\circ} \mathrm{F}\left(12.8^{\circ} \mathrm{C}\right)$.

- Daytime temperatures too high, above $90^{\circ} \mathrm{F}\left(32.2^{\circ} \mathrm{C}\right)$.

- Excessive smog during blossoming period.

- Excess nitrogen fertilizer.

- Too much shade.

- Plants set out too early in spring.

- Poorly adapted variety.

\section{Control}

- Choose varieties adapted to your climate zone, plant tomatoes in full sun, keep soil evenly moist, and avoid excessive nitrogen fertilizer.

- Hormone sprays can improve fruit set during low temperatures, but will not help in high temperatures.

- Tapping on blossom stems 3 times a week at midday when flowers are open may improve pollination and help set fruit.

\section{Solar Yellowing and Green Shoulders}

\section{Problem}

- Yellow or yellow-orange color instead of normal red. 
- Upper portions of fruit may remain green even though the lower portions appear red ripe.

Probable Cause

- High temperatures and high light intensity.

Control

- Maintain plant vigor to produce adequate leaf cover.

- Avoid overpruning.

- Provide partial shade (e.g., shade cloth, screening material) during hours of most intense sunlight.

\section{Sunburn}

Problem

- Fruit turns light brown and leathery on side exposed to the sun.

\section{Probable Cause}

- Overexposure to sunlight.

\section{Control}

- Maintain plant vigor to produce adequate leaf cover.

- Avoid overpruning.

- Provide partial shade (e.g., shade cloth, screening material) during hours of most intense sunlight.

\section{Leaf Roll}

\section{Problem}

- Older leaves roll upward and inward rather suddenly, become stiff to the touch, brittle, and leathery.

\section{Probable Cause}

- High light intensity and high soil moisture, particularly when plants are staked and heavily pruned. Some varieties are more susceptible than others.

\section{Control}

- Choose less-susceptible varieties.

- Maintain even soil moisture.

- Provide partial shade during periods of intense sunlight.

\section{Blossom End Rot}

\section{Problem}

- Water-soaked spot on blossom end of fruit enlarges and darkens, becomes sunken and leathery. Affects both green and ripe fruit, and is more common on sandier soils.

\section{Probable Cause}

- Calcium nutrition and water balance in the plant, aggravated by high soil salt content and fluctuating soil moisture.

\section{Control}

- Maintain even soil moisture.

- Amend planting area with organic matter such as compost to improve water retention.

- Avoid heavy applications of high-nitrogen fertilizer.

- Soils that are deficient in calcium may be amended with gypsum. 


\section{Fruit Cracks and Catfacing}

Problem

- Circular concentric cracks around the stem end (concentric cracking).

- Cracks radiating outward from the stem (radial cracking).

- Malformation and cracking at the blossom end (catfacing).

Probable Cause

- Periods of very fast growth with high temperatures and high soil moisture levels.

- Wide fluctuations in soil moisture content or heavy rain following a dry period.

- Wide differences in day and night temperatures. Catfacing may be caused by abnormally cool or hot conditions.

- Any disturbance to the flower parts during blossoming.

- Some varieties are more susceptible to cracks and catfacing than others.

\section{Control}

- Choose varieties that are adapted to your climate zone and are less susceptible to cracking.

- Keep soil evenly moist.

- Maintain good leaf cover or provide partial shade in periods of high light intensity.

- A layer of organic mulch 3 to 4 inches ( 7.5 to $10 \mathrm{~cm}$ ) deep such as compost helps moderate soil temperatures and soil moisture fluctuations.

\section{Puffiness}

Problem

- The tomato resembles a bell pepper, with normal outer walls and a hollow inside.

\section{Probable Cause}

- Conditions that interfere with normal pollination, such as temperatures above $90^{\circ} \mathrm{F}$ $\left(32.2^{\circ} \mathrm{C}\right)$ or below $55^{\circ} \mathrm{F}\left(12.8^{\circ} \mathrm{C}\right)$.

- Low light.

- Excessive nitrogen fertilizer or heavy rainfall.

- The condition seems to occur most frequently in early harvests.

\section{Control}

- Select varieties adapted to your climate zone.

- Avoid excessive application of nitrogen fertilizer.

\section{COMMON PESTS OF TOMATOES}

Home gardeners often discover damage to foliage and fruit of tomato plants caused by a variety of pests, including hornworms, tomato fruitworms, tomato pinworms, stink bugs, whiteflies, and leafminers. For photographs and information regarding identification and management of these pests, refer to UC IPM Pest Management Guideline: Tomato at the UC IPM Web site, http://Www.ipm.ucdavis.edu/PMG/selectnewpest. tomatoes.html; if you know the specific pest, refer to the online Pest Notes at the UC IPM W eb site, http://www.ipm.ucdavis.edu/PMG/selectnewpest.landscape.html. 


\section{FOR MORE INFORMATION}

Pests of the Garden and Small Farm, 2nd ed., ANR Publication 3332, 1998.

California Master Gardener Handbook, ANR Publication 3382, 2002.

UC Guide to Solving Garden and Landscape Problems (CD-ROM), ANR Publication 3400, 2000.

UC IPM Pest Management Guideline: Tomato

http://ipm.ucdavis.edu/PMG/selectnewpest.tomatoes.html.

UC IPM Pest Notes http://www.ipm.ucdavis.edu/PMG/selectnewpest.landscape.html.

Vegetable Garden Basics, ANR Publication 8059, 2002 http://anrcatalog.ucdavis.edu/pdf/8059.pdf.

UC Cooperative Extension Vegetable Research and Information Center Web site, http://vric.ucdavis.edu.

To order or obtain printed publications and other products, visit the ANR Communication Services online catalog at http://anrcatalog.ucdavis.edu. You can also place orders by mail, phone, or FAX, or request a printed catalog of our products from:

University of California

Agriculture and Natural Resources

Communication Services

6701 San Pablo Avenue, 2nd Floor

Oakland, California 94608-1239

Telephone: (800) 994-8849 or (510) 642-2431

FAX: (510) 643-5470

E-mail inquiries: danrcs@ucdavis.edu

An electronic version of this publication is available on the ANR Communication Services Web site at http://anrcatalog.ucdavis.edu.

Funding for this publication was made possible through a grant from the Elvenia J. Slosson Fund.

Publication 8159

(c) 2005 by the Regents of the University of California, Division of Agriculture and Natural Resources. All rights reserved.

The University of California prohibits discrimination or harassment of any person on the basis of race, color, national origin, religion, sex, gender identity, pregnancy (including childbirth, and medical conditions related to pregnancy or childbirth), physical or mental disability, medical condition (cancer-related or genetic characteristics), ancestry, marital status, age, sexual orientation, citizenship, or status as a covered veteran (covered veterans are special disabled veterans, recently separated veterans, Vietnam era veterans, or any other veterans who served on active duty during a war or in a campaign or expedition for which a campaign badge has been authorized) in any of its programs or activities. University policy is intended to be consistent with the provisions of applicable State and Federal laws.

Inquiries regarding the University's nondiscrimination policies may be directed to the Affirmative Action/Staff Personnel Services Director, University of California, Agriculture and Natural Resources, 300 Lakeside Drive, 6th Floor, Oakland, CA 94612-3550 (510) 987-0096. For a free catalog of other publications, call (800) 994-8849. For help downloading this publication, call (530) $297-4445$.

This publication has been anonymously peer reviewed for technical accuracy by University of California scientists and other qualified professionals. This review process was managed by the ANR Associate Editor for Vegetable Crops. 